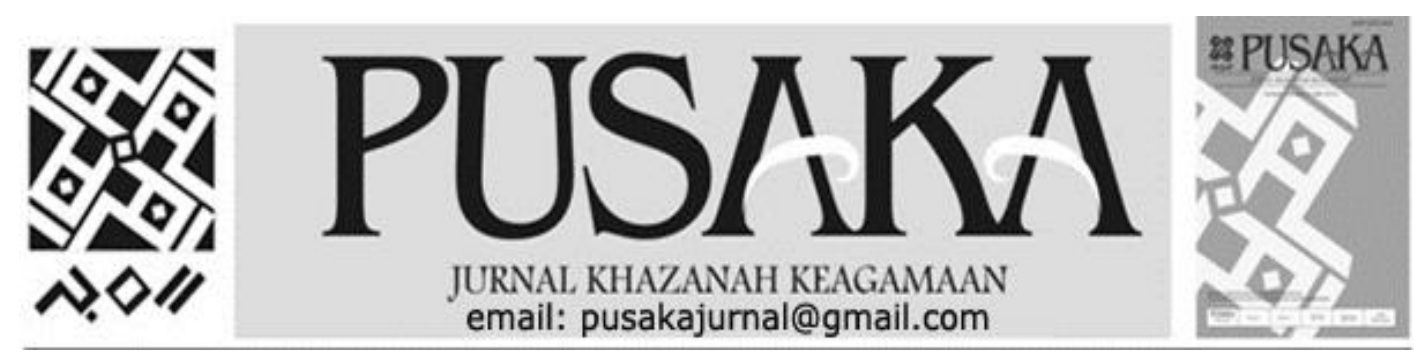

\title{
Pengkaderan Ulama di Ma'had Aly Pondok Pesantren DDI Mangkoso Kabupaten Barru Provinsi Sulawesi Selatan
}

\author{
The School of Ulama in Ma'had Aly Islamic Boarding School DDI Mangkoso, \\ Barru District South Sulawesi Province
}

Muhammad Sadli Mustafa

Balai Penelitian dan Pengembangan Agama Makassar

Jl.A.P.Pettarani No.72 Makassar. Telp:0411-452952

Email: muhammadsadlimustafa@gmail.com

\begin{tabular}{|c|c|}
\hline $\begin{array}{c}\text { Info } \\
\text { Artikel } \\
\end{array}$ & Abstract \\
\hline $\begin{array}{c}\text { Diterima } \\
6 \\
\text { September } \\
2018 \\
\\
\text { Revisi I } \\
2 \\
\text { Oktober } \\
2018\end{array}$ & $\begin{array}{l}\text { Penelitian ini bertujuan untuk mengetahui pola pengkaderan ulama di Sulawesi } \\
\text { Selatan dengan fokus kajian Ma'had Aly DDI Mangkoso, Barru. Penelitian ini } \\
\text { menggunakan pendekatan kualitatif. Pengumpulan data dilakukan dengan } \\
\text { wawancara, observasi, studi literatur dan dokumentasi. Hasil penelitian } \\
\text { menunjukkan bahwa pengkaderan ulama di Sulawesi Selatan sebenarnya telah } \\
\text { lama dilakukan di beberapa Pondok Pesantren. Khusus di Barru, pengkaderan } \\
\text { ulama dalam bentuk Ma'had Aly baru dimulai sejak tahun 2013. Hingga kini } \\
\text { masih sedang berlangsung dan belum menelurkan alumni. Masa pengkaderannya } \\
\text { empat tahun untuk satu angkatan dengan kurikulum berupa ilmu-ilmu alat seperti } \\
\text { ilmu lugah (bahasa) khususnya bahasa Arab, Usul Fikih, Usul Tafsir, Usul Hadis, } \\
\text { serta Aqidah/ilmu Tauhid yang bersumber dari Kitab-kitab klasik yang dipelajari } \\
\text { hingga tuntas dalam sistem tradisional yakni dalam bentuk pengajian halaqah. } \\
\text { Semua mahasantri di Ma'had ini dibebaskan dari segala bentuk biaya pendidikan. } \\
\text { Yang unik dari sistem pendanaan di Ma'had ini adalah menggunakan pola orang } \\
\text { tua angkat/asuh yang menyumbangkan dana setiap bulan selama program ini } \\
\text { berlangsung meskipun tetap menerima sumbangan dari para donatur lainnya dan } \\
\text { juga pemerintah khususnya pemerintah setempat. } \\
\text { Kata Kunci: Ma'had Aly, Pondok Pesantren, DDI Mangkoso }\end{array}$ \\
\hline $\begin{array}{c}\text { Revisi II } \\
13 \\
\text { Oktober } \\
2018 \\
\text { Disetujui } \\
1 \\
\text { November } \\
2018\end{array}$ & $\begin{array}{l}\text { This study aims to determine the pattern of cadre formation in South Sulawesi with } \\
\text { a focus on the study of Ma'had Aly DDI Mangkoso, Barru. This study uses a } \\
\text { qualitative approach. Data collection is done by interviewing, observing, studying } \\
\text { literature and documentation. The results showed that the formation of ulama in } \\
\text { South Sulawesi had actually been carried out in a number of Islamic boarding } \\
\text { schools. Especially in Barru, the formation of scholars in the form of Ma'had Aly } \\
\text { has only begun since 2013. Until now it is still ongoing and has not yet produced } \\
\text { alumni. The four-year cadre period for one generation with the curriculum in the } \\
\text { form of science tools such as linguistics (language), especially Arabic, Proposed } \\
\text { Fiqh, Proposed Interpretation, Proposed Hadith, and Aqeedah / Tawheed } \\
\text { knowledge derived from the classical Scriptures which are studied to the fullest in } \\
\text { traditional system that is in the form of halaqah recitation. All mahasantri at } \\
\text { Ma'had are exempt from all forms of tuition fees. What is unique about the funding } \\
\text { system in Ma'had is to use a pattern of foster parents who donate funds every } \\
\text { month during this program despite receiving donations from other donors and the } \\
\text { government, especially the local government. } \\
\text { Keywords: Ma'had Aly, Islamic Boarding Schools, DDI Mangkoso }\end{array}$ \\
\hline
\end{tabular}




\section{PENDAHULUAN}

Ulama merupakan pewaris para Nabi (al-Sijistani, t.th.: 354). Oleh karena itu, tugas utama yang mesti diemban adalah mengacu pada tugas utama para nabi yakni menyampaikan/tablig ajaran-ajaran Tuhan (QS. Al-Ma'idah/5: 67), menjelaskan ajaran-ajaran-Nya (QS. Al-Nahl/16: 44), memutuskan perkara atau problem yang dihadapi masyarakat (QS. Al-Baqarah/2: 213), dan memberikan contoh pengamalan dan akhlaq berdasarkan hadis riwayat Bukhari dari Aisyah ra. yang menyatakan bahwa prilaku Nabi saw. adalah praktik dari al-Qur'an (Shihab, 2007: 1019). Berdasarkan pandangan Quraish Shihab ini maka dapat dikatakan bahwa setidaknya ada empat fungsi yang mesti diemban oleh ulama sebagai pewaris Nabi yaitu, fungsi tablig, tibyan, tahkim, dan uswah hasanah.

Sejalan dengan itu, Azyumardi Azra mengungkapkan bahwa ulama memiliki dua kategori yakni kategori keagamaan dan kategori sosiologis. Ulama sebagai kategori keagamaan merupakan pewaris para nabi yakni pemangku ilmu agama yang bersifat ilahiyah dan sakral yang memiliki otoritas dalam pengetahuan keislaman. Ulama sebagai kategori sosiologis dalam arti mampu memahami perubahan sosial dan implikasinya terhadap Islam dan kehidupan kaum muslim. Sehingga dapat memberikan arah dan bimbingan kepada umat dalam mengantisipasi dan merespons gejolak perubahan (Azra, 2013: 3-4).

Fungsi dan peran ulama tersebut tentu semakin dibutuhkan oleh masyarakat Indonesia saat ini di tengah kuatnya arus globalisasi dan perkembangan teknologi yang semakin cepat, di tambah banyaknya aliran paham yang berkembang di masyarakat. Hanya saja, ulama adalah figur yang semakin langka saat ini. Kondisi tersebut menunjukkan butuhnya terhadap kader ulama yang mumpuni untuk memberi pencerahan terhadap masyarakat sekaligus sebagai teladan umat. Satu hal yang patut disyukuri khususnya oleh umat Islam Indonesia adalah bahwa sudah ada regulasi yang mengatur tentang kelembagaan kaderisasi ulama ini khususnya terkait dengan Ma'had Aly yakni Peraturan Menteri Agama Nomor 71 Tahun 2015 tentang Ma'had Aly. Dengan terbitnya regulasi ini maka posisi Ma'had Aly setara dengan perguruan tinggi keagamaan lainnya.

Di Kawasan Timur Indonesia (KTI) terdapat beberapa lembaga keagamaan yang melakukan pengkaderan atau Pendidikan Kader Ulama (PKU) dari tahun ke tahun. Di Sulawesi Selatan misalnya, terdapat lembaga keagamaan atau pondok pesantren yang melaksanakan program pengkaderan ulama. Ada yang masih eksis hingga sekarang di antaranya seperti Pondok Pesantren As'adiyah Sengkang dan Ma'had Aliy DDI Mangkoso, Barru. Ada pula yang akhirnya vakum seperti Hai'atuttakaful (PKU kerjasama beberapa pondok pesantren di Sulawesi Selatan di jaman orde baru dahulu), PKU Yayasan Masjid Raya Makassar dan PKU di Soppeng. Sementara di Sulawesi Tengah, juga pernah ada lembaga keagamaan yang melaksanakan PKU seperti Majelis Ulama Indonesia (MUI) Provinsi Sulawesi Tengah yang saat ini juga telah vakum. Pola pembinaan yang 
dilakukan oleh masing-masing lembaga tersebut berbeda-beda. Dari sisi masa/lama pendidikannya saja sudah berbeda. Misalnya, ada yang hanya setahun atau dua tahun saja. Ada pula hingga 3 atau 4 tahun. seperti Pondok Pesantren As'adiyah Sengkang dan Pondok Pesantren DDI Mangkoso.

Demikianlah, sehingga penting untuk dilakukan penelitian terkait pengkaderan ulama yang dilakukan oleh lembaga keagamaan yang menyelenggarakan PKU khususnya di Barru, Sulawesi Selatan. Penelitian ini dilakukan untuk mengetahui dan mengungkap pola pembinaan yang diterapkan di Ma'had Aly Pondok Pesantren DDI Mangkoso, Barru, dan faktor-faktor yang mendukung dan menjadi penghambat terselenggaranya PKU di Ma'had Aly Pondok Pesantren DDI Mangkoso, Barru.

\section{Deskripsi Fokus Penelitian \\ Pola Pengkaderan}

Kata pola bermakna sistem atau cara kerja, dapat juga bermakna bentuk atau struktur yang tetap, dan dapat pula bermakna proses (Tim Penyusun Kamus, 1990: 692). Kata proses bermakna rangkaian tindakan, pembuatan, atau pengolahan yang menghasilkan produk (Tim Penyusun Kamus, 1990: 703). Sedangkan sistem bermakna seperangkat unsur yang secara teratur saling berkaitan sehingga membentuk suatu totalitas (Tim Penyusun Kamus, 1990: 849). Berdasarkan makna tersebut maka dalam penelitian ini yang dimaksud pola adalah serangkaian upaya yang dilakukan oleh lembaga keagamaan tertentu menurut sistem tertentu yang diterapkan untuk menghasilkan suatu produk.

Kata pengkaderan atau kaderisasi biasanya identik dengan organisasi. Pengkaderan atau kaderisasi dalam sebuah organisasi dipahami sebagai sebuah proses mempersiapkan calon-calon pemimpin suatu organisasi untuk waktu sekarang dan masa yang akan datang demi kesinambungan organisasi (Parwadi, 2006: 4 - 5). Dapat juga dikatakan pengkaderan adalah suatu kejadian yang ditujukan pada usaha-usaha proses pembentukan kader (Tamrin, t.th.: 3).

Pengkaderan ulama yang dimaksud dalam penelitian ini adalah proses atau serangkaian upaya yang dilakukan oleh lembaga keagamaan tertentu menurut suatu sistem yang diterapkan dalam rangka mempersiapkan kader-kader ulama yang dibekali dengan ilmu dan wawasan pengetahuan agama Islam yang luas dan mendalam serta wawasan pengetahuan lainnya untuk dapat berkiprah di masyarakat kelak memberi pencerahan agama, akhlak, dan keteladanan.

\section{Ulama}

Kata alim dalam Kamus Besar Bahasa Indonesia, bermakna berilmu, berpengetahuan, pandai dan saleh. Dari kata ini, terdapat kata kealiman yang berarti kepandaian (dalam hal agama) dan kesalehan (berkelakuan baik). Kata ulama dipakai sebagai kata tunggal yang bermakna orang yang ahli dalam hal atau dalam pengetahuan Islam (Tim Penyusun Kamus, 1990: 22 dan 985).

Kata ulama pada dasarnya adalah serapan dari bahasa arab yakni 'ulama'. Kata ini merupakan bentuk jamak dari kata 'alim (al- 
Ma'luf, 1986: 527) yang bermakna orang yang mengetahui, orang yang berilmu, terpelajar, atau cendekiawan (Munawwir, 1997: 966). Kata ini dalam berbagai bentuknya ( $f$ 'il/kata kerja maupun isim/kata benda) disebut 863 kali dalam al-Qur'an. Sedangkan khusus kata 'ulama hanya disebut 2 kali dalam al-Qur'an yakni dalam Q.S. Fathir/35: 28 dan alSyu'ara'/26: 197. Dalam QS. Fathir, kata 'ulama disebut dalam konteks ajakan al-Qur'an untuk memerhatikan turunnya hujan dari langit, keanekaragaman buahbuahan, gunung binatang, dan manusia, yang kemudian diakhiri dengan kalimat berkenaan dengan hamba yang paling takut kepada Tuhan adalah ulama. Ayat ini mengisyaratkan bahwa ulama adalah orang yang memiliki pengetahuan tentang ayat-ayat Allah yang bersifat Kauniyyah (kosmos). Sedangkan dalam QS. Al-Syu'ara', kata 'ulama' disebut dalam konteks pembicaraan tentang kandungan alQur'an yang telah diakui (diketahui) oleh 'ulama' bani Isra'il. Ini mengisyaratkan bahwa ulama adalah orang-orang yang memiliki pengetahuan tentang ayat-ayat qur'aniyyah. Oleh karena itu, 'ulama' dalam konsep al-Qur'an berarti orang-orang yang memiliki pengetahuan tentang ayat-ayat Allah baik yang bersifat kauniyyah maupun yang bersifat qauliyyah yang dapat mengantar kepada sikap tunduk dan takut kepada Allah (Shihab, 2007: 1018-1019).

Ulama bagi orang Bugis disebut Gurutta yang secara harfiah bermakna guru kita. Gurutta adalah orang yang ahli dalam bidang agama (Islam) yang diterima dan ditokohkan oleh masyarakat. Penokohan itu didasarkan pada aspek kompetensi keilmuan, kompetensi sosial (amalan agama) dan kompetensi kepribadian atau akhlak (Ahmad, 2009: 457).

Pondok Pesantren

Kata pondok dalam kaitannya dengan pesantren dapat bermakna asrama bagi para santri (Dhofier, 1994: 18). Sedangkan kata pesantren, disinyalir berasal dari kata "santri" dengan penambahan awalan "pe" dan akhiran "an" menjadi pesantren (Ziemek, 1986: 99; Damopolii, 2005: 57). Sejalan dengan pengertian ini, menurut Mastuhu (1994: 88), dunia pesantren tidak selalu tampak seragam. Masing-masing memiliki keunikan-keunikan tersendiri. Olehnya itu, sulit dibuat sebuah perumusan yang dapat menampung semua pesantren secara komprehensif. Namun, pengertian pesantren dapat digali dari asal-usul kata pesantren itu sendiri yang secara umum dimaknai sebagai tempat tinggal para santri.

Ma'had Aly

Ma'had (bahasa Arab) bila dimaknai dalam Bahasa Indonesia lebih banyak diartikan pesantren, sementara 'aly berarti tinggi. Jadi, ma'had aly adalah pesantren tingkat tinggi, sejajar dengan perguruan tinggi. Ma'had Aly yang dimaksudkan di sini adalah sebuah lembaga kaderisasi ulama yang diselenggarakan oleh pondok pesantren yang menyelenggarakan pendidikan dalam rangka penguasaan ilmu agama Islam (tafaqquh fiddin) berbasis kitab kuning. Pengertian ini sejalan dengan yang disebutkan dalam PMA Nomor 71 Tahun 2015 Pasal 1 ayat 1. 


\section{Kajian yang Relevan}

Penelitian dan tulisan terkait ulama sebenarnya sudah cukup banyak yang terpublikasi dengan berbagai macam metode dan sudut pandang. Ada yang terkait dengan jaringan ulama di antaranya karya Azyumardi Azra yang sudah sejak lama populer (Azra, 1994). Ada yang menyoroti dari sisi pandangan masyarakat terhadap ulama seperti karya Abd. Kadir Ahmad dalam disertasinya yang kemudian dipulikasikan dengan judul Ulama Bugis yang mengungkap pandangan masyarakat Bugis tentang ulama, pandangan keagamaan ulama, peran ulama dalam dinamika sosial, dan pola hubungan ulama dan masyarakat (Ahmad, 2009).

Selain itu, juga cukup banyak yang mengkaji tentang sisi pribadi kehidupan ulama dalam bentuk biografi misalnya ulama di Sulawesi Selatan. Karya biografi dimaksud di antaranya karya Ruslan dan Waspada Santing yang berjudul "Ulama Sulawesi Selatan, Biografi Pendidikan dan Dakwah." Tulisan ini mengungkap biografi 14 orang ulama yang dikenal di Sulawesi Selatan dan beberapa di antaranya dikenal secara nasional, seperti AG. H. Muhammad As'ad dan AG. H. Ambo Dalle (Ruslan dan Waspada Santing, 2007).

Karya lainnya adalah "Buah Pena Sang Ulama" merupakan sebuah buku yang juga membahas tentang biografi beberapa ulama dan karya tulisnya di Kawasan Timur Indonesia (Muh. As'ad, dkk., 2011). Ada juga yang membahas secara khusus biografi seorang ulama kharismatik Sulawesi Selatan dalam sebuah buku yang berjudul
"Pengabdian tanpa Batas: Biografi Anregurutta Haji Abdul Malik Muhammad", tulisan ini merupakan buah karya Saprillah (2014).

Terdapat pula beberapa penelitian maupun tulisan yang membahas tentang pesantren yang ada di Sulawesi Selatan. Misalnya disertasi Wahyuddin Halim (2015) yang membahas terkait tradisi As'adiyah dalam merekonstruksi dan mereproduksi ulama di Sulawesi Selatan. Selain itu, ada juga disertasi Agus Muchsin (2014) yang membahas tentang manhaj fikih Pesantren As'adiyah Sengkang dan DDI Mangkoso, Barru.

Namun demikian, belum ditemukan adanya penelitian yang khusus membahas tentang pola pengkaderan ulama khususnya di Ma'had Aly DDI Mangkoso, Barru. Oleh karena itu, penelitian ini lebih difokuskan pada pola atau proses pengkaderan ulama di Ma'had Aly DDI Mangkoso, Barru, Sulawesi Selatan.

\section{Metode Penelitian}

Penelitian ini merupakan penelitian kualitatif yang berupaya untuk mengungkap secara deskriptif pengkaderan ulama di lembaga keagamaan yang melakukan aktifitas tersebut dalam hal ini Ma'had 'Aly Pondok Pesantren DDI Mangkoso, Barru, Sulawesi Selatan.

Data yang dikumpulkan dalam penelitian ini adalah data tentang latar belakang dan riwayat lembaga yang melakukan pengkaderan ulama sasaran termasuk situasi dan kondisi lingkungan di mana lembaga tersebut berada, sistem pembinaan yang diterapkan termasuk dalam hal ini kurikulum dan kitab-kitab yang 
selama ini dipakai, dan perkembangannya dari masa ke masa. Sumber data adalah para informan yang memiliki keterkaitan erat dengan lembaga pengkaderan ulama sasaran dalam hal ini pimpinan, staf, dan tenaga pembina. Juga kader dan alumni lembaga sasaran. Informan juga dapat berasal dari masyarakat dan tokohnya serta stake holder dari Kantor Kementerian Agama di lokasi penelitian serta pihak lainnya yang berkaitan dengan penelitian ini. Selain itu, didukung dengan dokumen atau kepustakaan yang relevan dengan penelitian ini.

Teknik pengumpulan data yang digunakan dalam penelitian ini adalah sebagaimana lazimnya dalam penelitian kualitatif yaitu wawancara, observasi, dan studi pustaka/dokumentasi. Salah satu ciri penelitian kualitatif, yang menjadi instrumen adalah peneliti (Sugiyono, 2010: 305). Oleh karena itu, analisis data dilakukan sejak penelitian ini berlangsung hingga proses pengumpulan data berakhir. Namun, lebih difokuskan selama proses pengumpulan data di lokasi penelitian (Sugiyono, 2010: 336). Data yang dikumpulkan selama penelitian, dianalisis pada tingkat reduksi data, disajikan dan dijelaskan secara deskriptif. Dalam arti bahwa, proses analisis data dilakukan secara interaktif dan berlangsung terus menerus sampai datanya jenuh.

\section{PEMBAHASAN}

\section{Gambaran Umum Pengkaderan Ulama di Kabupaten Barru, Sulawesi Selatan}

Provinsi Sulawesi Selatan dikenal sebagai salah satu provinsi yang banyak mencetak ulama. Di setiap masa selalu ada tokoh-tokoh ulama kharismatik yang muncul. Bahkan, hingga di era abad ke-20, ada beberapa ulama kharismatik yang tampil memberi pencerahan pada masyarakat dan juga mengkader generasi pelanjut untuk menjadi ulama. Mereka antara lain Anregurutta Haji (AGH.) As'ad, AGH. Ambo Dalle, AGH. Yunus Martan, AGH. Abdul Malik, AGH. Junaid Sulaiman, dan para Anregurutta lainnya yang konsisten melanjutkan pengkaderan ulama melalui lembaga pendidikan yang mereka bina. Hingga suatu masa pernah dibentuk sebuah wadah pengkaderan ulama yang merupakan wujud kerjasama antar lembaga yang masing-masing para ulama/anregurutta tersebut bina yang disebut dengan Hai'atuttakaful. Lembaga ini sempat menelurkan sejumlah ulama yang mumpuni. Hanya saja lembaga ini berjalan sekitar kurang lebih satu dasarawarsa. Dalam masa itu lembaga ini mampu menamatkan 3 angkatan. Masa pengkaderan satu angkatan sekitar tiga sampai empat tahun. Setelah itu, karena terkendala beberapa hal, akhirnya lembaga ini vakum. Meskipun demikian, lembaga yang pernah tergabung dalam wadah tersebut, ada di antaranya yang masih tetap konsisten membina kader ulama secara mandiri seperti Pondok Pesantren As'adiyah Sengkang. Sementara Anregurutta lainnya pun masingmasing tetap membina generasi muslim melalui pondok pesantren yang telah mereka rintis sebelumnya yang kemudian dilanjutkan oleh generasi setelahnya. 
Salah satu pondok pesantren yang merupakan warisan salah satu ulama kharismatik Sulawesi Selatan, AGH. Ambo Dalle, yaitu Pondok Pesantren DDI Mangkoso di Barru yang masih bertahan hingga sekarang. Bahkan, sudah semakin berkembang. Dan saat ini telah memiliki pula lembaga khusus untuk menelurkan kader ulama.

Di Kabupaten Barru, sebenarnya terdapat 4 pondok pesantren yakni:

1. Pondok Pesantren DDI Amburrahman Ambo Dalle, Mangkoso, didirikan tahun 1938, saat ini dipimpin oleh AGH. Prof. Dr. M. Faried Wadjedy, MA.

2. Pondok Pesantren alMunawwarah, Bottoe, didirikan tahun 1982, dipimpin oleh KH. Husain Aliyah

3. Pondok Pesantren DDI alIkhlash Addary, Takkalasi, didirikan tahun 1992, dipimpin oleh Drs. K. Manshur Musthafa, dan

4. Pondok Pesantren al-Taufiq, Pekkae, didirikan tahun 1952, dipimpin oleh H. Ismail Hannanong, Lc.

Sangat disayangkan, lembaga yang disebut terakhir di atas, saat ini tidak lagi diakui oleh Kementerian Agama Kabupaten Barru sebagai pondok pesantren karena tidak lagi memenuhi syarat sebagai lembaga yang layak disebut sebagai pondok pesantren (Ahmad Rasyid, Kasi Pontren, wawancara, 5 Agustus 2016).

Meskipun ada beberapa pondok pesantren di Barru seperti diungkapkan di atas, namun hanya satu pondok pesantren yang membina atau membentuk lembaga khusus untuk mengkader ulama yaitu Pondok Pesantren DDI Mangkoso, yang dibina oleh AGH. Prof. Dr. M. Faried Wadjedy, MA.

\section{Pola Pembinaan di Ma'had Aly Pondok Pesantren DDI Barru}

Sebagaimana telah disebutkan sebelumnya bahwa di Kabupaten Barru hanya ada satu lembaga yang didirikan khusus untuk pendidikan kader ulama yaitu Ma'had Aly alTabi' li Dari al-Da'wah wa al-Irsyad (Pendidikan Tinggi Kader Ulama DDI Amburrahman Ambo Dalle), Mangkoso. Didirikan sekitar tiga tahun silam. Tepatnya, dibuka pada tanggal 5 November 2013/1 Muharram 1434 H. (Syamsu Rijal, Pengurus Lembaga, wawancara, 3 Agustus 2016). Pendirian lembaga ini dilatarbelakangi oleh keprihatinan pimpinan pondok pesantren, AGH. M. Faried Wadjedy dan pengurus melihat kelangkaan ulama. Sementara masyarakat saat ini sangat membutuhkan figur-figur ulama yang menuntun mereka menjalankan ajaran agama dalam kehidupannya (AGH. M. Farid Wadjedy, wawancara, 5 Agustus 2016).

Masa pengkaderan di lembaga ini adalah 4 tahun setiap satu angkatan. Saat ini, angkatan I masih sedang berlangsung. Penerimaan kader baru dilaksanakan setiap selesai satu angkatan atau 4 tahun sekali (Aidy Syam, Pengurus dan Pembina, wawancara, 4 Agustus 2016).

Penjaringan kader dilakukan lembaga ini dengan sosialisasi kepada para alumni Pondok Pesantren DDI Mangkoso dan melalui surat permintaan utusan yang 
dikirim ke Kementerian Agama Kabupaten/Kota di Sulawesi Selatan. Namun, ternyata cara yang disebut terakhir ini kurang efektif. Sehingga yang mengikuti seleksi penerimaan kader ulama di lembaga ini justru para alumni, baik tamatan Aliyah maupun yang sudah sarjana, bahkan ada yang telah menjadi pembina/guru di pondok pesantren DDI Mangkoso. Penjaringan kader angkatan I di lembaga ini diikuti oleh lebih dari 50 orang peserta. Namun, yang memenuhi syarat hanya 27 orang, 3 di antaranya adalah perempuan.

Materi yang diujikan pada seleksi penerimaan adalah qira'atul kutub (pembacaan kitab "gundul") dengan objek penilaian pada 3 aspek yaitu aspek kecakapan membaca dengan qawa'id (kaidah-kaidah)-nya, aspek kecakapan menerjemah secara teks dan konteks, dan aspek kecakapan memahami dan kemampuan merumuskan kesimpulan dari bacaan. Di samping itu, juga diuji kemampuan membaca Alquran dengan tajwidnya (Aidy Syam, Pengurus dan Pembina, wawancara, 4 Agustus 2016).

Dosen yang membina maddah/mata kuliah disesuaikan dengan latar belakang keilmuannya. Pada umumnya, dosen-dosen tersebut adalah alumni Timur Tengah dalam hal ini alumni dari Universitas al-Azhar Cairo, Mesir. Karena, bahasa pengantar mata kuliah berbahasa Arab.

Daftar Dosen Ma'had 'Aly DDI Mangkoso dan maddah yang diampu dapat dilihat pada tabel berikut:

\begin{tabular}{|c|c|c|c|}
\hline No. & Nama Dosen & $\begin{array}{l}\text { Maddah Mata } \\
\text { Kuliah }\end{array}$ & Keterangan \\
\hline 1 & $\begin{array}{l}\text { Prof. Dr. A.G.H. M. Farid } \\
\text { Wadjedy, M.A. }\end{array}$ & Ushul Fighi & $\begin{array}{l}\text { Direktur } \\
\text { Ma'had/Dosen }\end{array}$ \\
\hline 2 & A.G.H. Zainuddin Said, M.A. & Ushul Tafsir & $\begin{array}{l}\text { Asisten } \\
\text { Direktur/Dosen }\end{array}$ \\
\hline 3 & Dr. H. Muh. Aydi Syam, M.H.I. & Ushul Fighi & $\begin{array}{l}\text { Sekretaris } \\
\text { Ma'had/Dosen }\end{array}$ \\
\hline 4 & Dr. H. Abdul Hakim Jurumiyah & Ushul Tafsir & Dosen \\
\hline 3 & G. H. Amiruddin Usman, Lc. & Ushul Hadis & Dosen \\
\hline 4 & H. Ismail Hannanong, Lc., M.Ag. & Ushul Hadis & Dosen \\
\hline 5 & H. Yamang Sahibe, Lc., M.Sy. & Hadis & Dosen \\
\hline 6 & H. Firdaus As'ad & Hadis & Dosen \\
\hline 7 & H. Ahmad Munir, Lc. M.Hum & Bahasa Arab & Dosen \\
\hline 8 & H. Syamsuddin, Lc., M.A. & Bahasa Arab & Dosen \\
\hline 9 & G.H. Abbas Remmang, Lc. & $\begin{array}{l}\text { Tauhid/Aqidah } \\
\text { dan Akhlaq }\end{array}$ & Dosen \\
\hline 10 & H. Muzakkir S.Ag., M.A. & $\begin{array}{l}\text { Tauhid/Aqidah } \\
\text { dan Akhlaq }\end{array}$ & Dosen \\
\hline
\end{tabular}

Adapun kitab-kitab yang menjadi rujukan di antaranya: 'Ilmu Usul al-Fiqh karya Abdul Wahab Khallaf, al-Qawa'id al-Fiqhiyyah alKubra wa Ma Tafarra'a 'anha karya Salih ibn Ganim Sadlan, Qawa'id alTafsir Jam'an wa Dirayatan karya Khalid ibn Usman al-Sabt, Dirasah fi 'Ulum al-Qur'an karya Muhammad bin Abdul Mun'im al-Khariba, Fath al-Mugis bi Syarhi Alfiyyah al-Hadis karya Muhammad ibn Abd alRahman al-Sakhawi, Qawa'id Usul al-Hadis karya Ahmad Umar Hasyim, Kayfa Nadrus 'Ilma Takhrij al-Hadis karya Hamzah 'Abdullah al-Malyabari \& Sultan al-'Akayah, Aqidah al-Mu'min karya Abu Bakar al-Jaza'iry, Syarah Ibnu 'Aqil 'ala al-Alfiyyah Ibnu Malik Karya Muhammad Muhyiddin Abd Hamid (jilid 2), Jawahir al-Balagah karya Ahmad al-Hasyimi dan beberapa kitab lainnya yang mendukung. Juga ada beberapa kitab yang menjadi materi tambahan di antaranya; kitab tentang Fikih seperti Khulasah ilmi al-Fara'idh (Makhtutah) karya Irsan Rauf, kitab tentang sejarah seperti al'Awasim min al-Qawasim karya Abu Bakr ibn al-'Arabi al-Maliki, Huqbah min al-Tarikh karya Usman ibn Muhammad al-Khamisy, dan juga kitab al-Mustakhlas fi Tazkiyah 
al-Anfus (akhlaq \& tasawwuf) karya Abdul Qadir Muhammad al-Bakar

Pola pembelajaran yang diterapkan di Ma'had Aly DDI Mangkoso ini adalah dalam bentuk pengajian halaqah saja dengan cara dosen yang membaca dan menjelaskan isi kitab (wetonan) dan juga dengan cara mahasantri yang membaca kitab lalu dosen yang menjelaskan (sorogan) yang sesekali diselingi dengan diskusi kecil atau tanya jawab antara dosen dan mahasiswa terkait suatu permasalahan tertentu terkait materi yang sedang dipelajari. Meskipun bentuk pembelajaran yang diterapkan masih tradisional tetapi ada juga dosen khususnya dosen hadis yang memperkenalkan dan mempraktekkan sistem pembelajaran dengan menggunakan teknologi modern yakni dengan menggunakan laptop dan LCD untuk menjelaskan dan mencari hadis secara cepat melalui aplikasi maktabah syamilah.

Dahulu, ketika baru dimulainya pembelajaran di Ma'had Aly ini, khususnya di fatrah awal (semester pertama), pembelajaran masih aktif dilakukan di masjid pesantren. Pada waktu itu, setiap kali pembelajaran dilakukan, mahasantri diwajibkan memakai pakaian seragam serba putih berupa gamis panjang, songkok, dan sorban. Demikian pula, dalam lingkungan mahasantri diterapkan budaya shalat lail/tahajjud berjama'ah. Bahkan, diwajibkan puasa Senin-Kamis (M. Idrus, mahasantri, wawancara, Rabu, 3 Agustus 2016). Namun, setelah masjid pesantren ini direnovasi, maka pembelajaran dipindahkan di lantai dua asrama khusus mahasantri Ma'had Aly di dalam ruangan berukuran $\pm 6 \times 4 \mathrm{~m}^{2}$. Budaya di lingkungan santri pun juga mulai ada yang berubah. Dalam pembelajaran tidak lagi konsisten dengan pakaian serba putih dan memakai sorban. Meski tetap sopan, namun, pakaiannya sudah berwarna-warni, sebagian ada yang memakai lengan panjang dan sarung, sebagian memakai celana panjang, sebagian memakai baju gamis panjang putih, sebagian lainnya memakai gamis panjang berwarna. Songkok yang dipakai pun tidak lagi konsisten putih-putih. Dan tak ada satupun yang memakai sorban lagi. Selain itu, mahasantri tidak lagi konsisten melakukan shalat lail secara berjama'ah tetapi secara sendirisendiri. Yang masih konsisten dibudayakan hingga kini oleh mahasantri adalah puasa SeninKamis (M. Idrus, mahasantri, wawancara, Rabu, 3 Agustus 2016).

Berkaitan dengan bahasa pengantar pada setiap pembelajaran, pada fatrah awal (semester pertama) hingga setahun masa pembelajaran di ma'had ini, bahasa pengantar dengan berbahasa Arab masih sangat intens diterapkan. Bahkan, mulai dari awal hingga akhir pembelajaran di semua maddah, baik ketika dosen menjelaskan maupun ketika mahasantri yang bertanya atau dalam diskusi. Namun, memasuki tahuntahun berikutnya, setelah pembina melakukan evaluasi, pada akhirnya tidak semua maddah lagi diajarkan dengan bahasa pengantar bahasa Arab, khususnya terkait dengan maddah hadis dan juga tafsir. Karena, ternyata ada sebagian mahasantri, masih agak kesulitan memahami materi tersebut jika terus diterapkan dengan bahasa pengantar 
bahasa Arab meski sesungguhnya semua mahasantri lancar membaca kitab "gundul". Sehingga, belakangan pada maddah tertentu sebagaimana yang disebutkan di atas, bahasa pengantar yang digunakan dalam setiap pembelajaran tidak lagi sepenuhnya berbahasa arab, tetapi diselingi dengan bahasa Indonesia dan juga sesekali bahasa Bugis (Ismail Hannanong, Dosen, wawancara, 1 September 2016).

Aktifitas pembelajaran di Ma'had ini dimulai hari Senin hingga Sabtu. Kebanyakan dimulai pagi hari dari pukul 08;00 hingga masuk waktu zuhur, adapula sebagian maddah yang jadwalnya di malam hari, terkadang pula jika dosen yang bersangkutan berhalangan untuk mengajar di waktu pagi biasanya dipindahkan di siang, atau sore, atau malam di hari yang sama.

Ada pula program pengembangan wawasan mahasantri dengan dilakukan semacam kuliah umum sekali dalam enam bulan. Dosen yang mengajar didatangkan dari Malaysia. Pembelajaran ini dilakukan selama 2 hari maraton. Selain itu, sekali sebulan dilakukan seminar. Yang menjadi narasumber adalah dosen secara bergilir. Sementara peserta adalah mahasantri dan juga dosen mitra. Bahasa pengantar dalam seminar ini adalah bahasa Arab. Juga ada kegiatan diskusi setiap ada kesempatan (sebelum atau setelah pembelajaran) yang disebut dengan bahsul masa'il yang difasilitasi oleh salah satu dosen Pembina. Diskusi ini merupakan inisiatif dari mahasantri untuk membahas isu-isu aktual baik terkait dengan agama maupun masalah sosial dan kebangsaan.
Untuk memperkuat kemampuan bahasa Arab mahasantri, pernah pula dilakukan perkampungan bahasa Arab di Pulau Dutungan Kabupaten Barru selama beberapa hari (M. Idrus, wawancara, 6 September 2016).

Mahasantri ma'had juga diwajibkan menghafal al-Qur'an minimal 5 juz (juz 1 - juz 5), Juz 'Amma, dan beberapa surah tertentu lainnya seperti al-Sajdah, Yasin, alWaqi'ah, al-Jumu'ah, al-Mulk, alQiyamah, dan al-Insan selama menjadi mahasantri. Kewajiban ini, sekaligus menjadi salah satu syarat penyelesaian program pendidikan kader ulama di Ma'had ini selain Ujian akhir dan kewajiban menulis sebuah risalah (semacam skripsi) (Aidy Syam, wawancara, 4 Agustus 2016 dan M. Idrus, wawancara, 1 September 2016).

Tahun pelajaran yang digunakan di Ma'had ini adalah tahun perhitungan bulan atau Hijriyah. Itulah sebabnya, fatrah awal/semester pertama dimulai pada bulan November 2013 yang lalu. Karena pada bulan itulah bertepatan dengan bulan Muharram 1434 H./ bulan pertama dalam perhitungan tahun Hijriyah. Oleh karena itu, hingga saat ini, belum ada satupun lulusan atau alumnus dari Ma'had ini. Sebab, pada saat penelitian ini berlangsung aktifitas pembelajaran baru memasuki fatrah al-sadis (semester enam). Pada semester ini pula diterapkan praktek lapangan yaitu semacam KKL selama 3 bulan dimulai bulan Ramadhan hingga Zulqa'dah. Meski demikian, aktifitas pembelajaran tetap berlangsung sejak beberapa hari pasca Idulfitri. Karena, praktek lapangan yang diterapkan 
tidak saling mengganggu dengan jadwal pembelajaran. Sebab, praktek lapangan ini berupa pengajian kitab di beberapa masjid di Kabupaten Barru antara Magrib dan Isya, sekali seminggu, selama 3 bulan dengan cara bergiliran. Beberapa masjid dimaksud antara lain, Masjid Hidayatullah Mattoanging, Masjid al-Mubarak Kiru-kiru, Masjid Babussalam Ajakkeng, Masjid alMubarak Lasijelling, dan Masjid alNur La Tappareng.

Ada pula diagendakan untuk mengirim mahasantri ke Timur Tengah dalam rangka mempermantap bahasa Arabnya sekaligus memperluas wawasannya sebelum para mahasantri tersebut selesai. Selain itu, juga diagendakan untuk pendidikan kader lanjutan (marhalah wustha) yang setara dengan strata dua (S.2) dan (marhalah 'ulya) strata tiga (S.3). Sehingga untuk gelar mahasantri program marhalah ula saat tamat diagendakan diberi gelar 'Alim. Jika program kader lanjutan berhasil maka gelar untuk alumni marhalah wustha adalah muhaqqiq (peneliti), dan gelar untuk alumni marhalah 'ulya adalah mujaddid atau mujtahid (Aidy Syam, wawancara, 4 Agustus 2016).

\section{Dukungan dan Hambatan Penyelenggaraan Pengkaderan Ulama di Ma'had Aly Pondok Pesantren DDI Mangkoso Barru}

Suatu lembaga pendidikan terkadang memiliki masalah dalam penyelenggaraan pendidikan. Untuk mengantisipasi masalah tersebut lembaga bersangkutan tentu punya cara tersendiri untuk keluar dari masalah. Pada umumnya, untuk pengembangan dan penyelenggaraan pendidikan di suatu lembaga biasanya tak lepas dari masalah pendanaan.

Masalah pendanaan dalam penyelenggaraan pendidikan kader ulama ini tentu sangat urgen. Karena, masalah ini bisa menjadi hambatan besar dalam penyelenggaraan pendidikan. Bahkan, dapat membuat suatu lembaga menjadi vakum karena kekurangan atau ketiadaan dana. Sebagai contoh, pengkaderan ulama yang diselenggarakan oleh MUI Sulawesi Selatan yang telah aktif sejak tahun 1992 pada akhirnya harus vakum. Bahkan, kevakumannya terjadi hingga 2 kali yakni tahun 2008 hingga 2011 dan 2014 hingga sekarang. Kevakuman itu, tidak terlepas dari kurangnya atau tidak adanya dukungan dana yang selama ini mensuplai operasional penyelenggaraan pengkaderan di lembaga ini (H. Said, wawancara, 4 September 2016).

Khusus untuk lembaga pengkaderan ulama di Barru yang diselenggarakan oleh Pondok Pesantren DDI Mangkoso Barru juga tak lepas dari masalah ini. Namun demikian, hal ini tidak melemahkan semangat para pengurus untuk tetap melanjutkan program pengkaderan ulama ini yang sejak awal telah menerapkan "pendidikan gratis" bagi mahasantri yang lulus seleksi. Apalagi masyarakat dan pemerintah sangat mendukung. Oleh karena itulah, sebelum masalah ini menjadi kendala yang bisa menghambat penyelenggaraan pendidikan di lembaga ini, para pengurus menawarkan program "orang tua angkat/asuh" pada masyarakat setiap kali mereka melakukan safari ke 
daerah-daerah. Bahkan sampai ke tanah Mandar Sulawesi Barat dan Papua khususnya Sorong, Papua Barat. Sehingga sampai saat ini masih konsisten para orang tua angkat yang berjumlah hingga 34 orang ini mensuplai dana satu juta rupiah setiap bulan untuk para anak angkat/asuh/mahasantri yang berjumlah 27 orang. Kelebihan sumbangan dari orang tua asuh ini digunakan oleh pengurus untuk pengembangan sarana prasarana termasuk pengadaan kitab-kitab yang umumnya disuplai dari Mesir.

Kendala teknis lainnya juga berasal dari keterbatasan waktu para dosen/Pembina ma'had. Karena, para dosen Ma'had selain sebagai dosen di Ma'had Aly juga bertindak sebagai dosen di STAI DDI Mangkoso yang bertetangga dengan Ma'had ini dan masih dalam satu naungan di bawah Pondok Pesantren DDI Mangkoso. Itulah sebabnya, Ma'had Aly ini tidak melakukan penerimaan kader baru --atau disebut juga calon mahasantri-- setiap tahun. Supaya para dosennya bisa fokus melakukan pembinaan. Sebab, pembinaan kader ulama itu mesti benar-benar fokus sehingga menghasilkan lulusan yang mumpuni (AGH. Farid Wadjedy, wawancara, 5 Agustus 2016).

Kendala lainnya adalah keterbatasan sarana prasarana. Ruang pembelajaran yang digunakan saat ini masih ruang darurat. Yakni di lantai 2 asrama mahasantri yang merupakan bangunan rumah kayu berlantai dua yang diwaqafkan oleh salah seorang warga Barru. Letaknya tepat dibelakang rumah Anregurutta Farid Wadjedy. Oleh Karena itulah, pengurus sedang mengusahakan untuk membangun sebuah gedung bertingkat di sebidang tanah waqaf yang disumbangkan oleh seorang warga lainnya di Barru. Tanah tersebut terletak di sebelah timur asrama mahasantri. Saat ini, baru pondasi bangunan tersebut yang jadi. Di lokasi itu, rencananya akan dibangun ruang/kantor Ma'had, aula serba guna, juga penginapan yang terintegrasi. Hal itu dilakukan untuk mengantisipasi kekurangan anggaran operasional lembaga ini di masa akan datang. Dalam bahasa pengurus, bangunan yang bisa "menghasilkan". Sementara, ruang pembelajaran utama nantinya adalah di Masjid setelah selesai direnovasi (Aidy Syam, wawancara, 4 Agustus 2016).

Selain itu, belum ada ruang perpustakaan khusus. Sehingga kitab-kitab yang ada masih belum tertata dengan rapi, bahkan hanya disusun secara sederhana tanpa rak dan diletakkan di dinding-dinding ruang pembelajaran sementara di lantai dua asrama mahasantri.

Satu hal yang patut diapresiasi dari pihak pemerintah khususnya pemerintah Kabupaten Barru adalah dukungannya terhadap penyelenggaraan pengkaderan ini. Bahkan, ketika lembaga ini masih dalam rencana, pemerintah Kabupaten Barru mendukung sepenuhnya untuk segera diwujudkan. Menurut informasi dari salah seorang pengurus Ma'had Aly ini bahwa Pemerintah Kabupaten Barru termasuk di antara pihak yang mengusulkan untuk membangun lembaga yang khusus mengkader ulama (Syamsu Rijal, Pengurus Lembaga, wawancara, 3 Agustus 2016). Sementara pihak Kementerian Agama Kabupaten Barru juga turut 
$\begin{array}{llr}\begin{array}{l}\text { mendukung } \\ \text { penyelenggaraan }\end{array} & \text { secara } & \text { moril } \\ \text { program }\end{array}$ pengkaderan ulama di lembaga ini misalnya dengan memfasilitasi pengurusan administrasinya agar segera bisa mendapat pengakuan dari pemerintah khususnya Kementerian Agama pusat sebagaimana beberapa Ma'had Aly lainnya yang telah lebih dahulu diakui termasuk dalam hal ini Ma'had Aly As'adiyah Sengkang, Wajo, Sulawesi Selatan (Ahmad Rasyid, Kasi Pontren Kementerian Agama Kabupaten Barru, wawancara, 5 Agustus 2016).

Dukungan penuh pemerintah itu diwujudkan tidak hanya dengan melakukan peletakan batu pertama pada awal didirikannya tetapi juga diwujudkan dengan menyumbangkan dana yang cukup besar yakni \pm 650 juta rupiah untuk pengembangan sarana prasarana Ma'had Aly.

Pada awalnya, dana itu diperuntukkan untuk pembangunan asrama dan ruang pembelajaran mahasantri. Namun, atas saran dari pemerintah, maka dana itu dialihkan untuk pembangunan/renovasi masjid pondok pesantren. Pengurus Ma'had tidak berkeberatan dalam hal ini. Karena, tempat pembelajaran utama pengkaderan ulama di lembaga ini memang di masjid (Aidy Syam, wawancara, 4 Agustus 2016). Masjid ini sekarang masih dalam pembangunan.

Selain itu, melalui Baznas Kabupaten Barru juga turut menyumbangkan anggaran dalam dua tahun terakhir sebanyak 100 juta rupiah yang masing-masing diberikan 50 juta rupiah per tahun. Meskipun Ma'had Aly ini mendapat dukungan moril dan materil dari beberapa pihak, namun hal itu masih belum sepenuhnya maksimal untuk mewujudkan semua agenda atau program pendidikan kader ulama di Ma'had ini yang memang membutuhkan biaya yang tidak sedikit (Aidy Syam, wawancara, 4 Agustus 2016).

\section{PENUTUP}

Pola pembelajaran di Ma'had
Aly DDI Mangkoso masih menggunakan sistem tradisional (sistem halaqah) dengan tetap menggunakan media teknologi terkini dalam pembelajaran.

Dana masih tetap menjadi kendala tersendiri bagi lembaga ini yang sama sekali tak memungut sepeserpun biaya dari mahasantrinya. Meskipun telah mendapatkan sokongan dana baik dari pemerintah setempat maupun dari donatur tetap dalam pola orang tua angkat/asuh dan donatur tidak tetap. Namun, dalam proses penyelenggaraan dan pengembangan Ma'had Aly ini ke depan masih tetap membutuhkan dukungan dana yang tidak sedikit dalam mewujudkan agenda-agenda Ma'had Aly ini.

\section{DAFTAR PUSTAKA}

Ahmad, Abd. Kadir. 2009. Ulama Bugis. Makassar: Penerbit Indobis Publishing.

As'ad, Muh. dkk. 2011. Buah Pena Sang Ulama. Cet. I; Jakarta: Orbit.

Azra, Azyumardi. 1994. Jaringan Ulama Timur Tengah dan Kepulauan Nusantara Abad ke17 dan 18. Bandung: Mizan. 2013. Problematika dan Prospek Kaderisasi Ulama: Inovasi Program Pengkaderan. 
Makalah. Disampaikan dalam Lokakarya 'Transformasi Model-model Pengkaderan Ulama di Masa Modern' yang dilaksanakan oleh Balai Penelitian dan Pengembangan Agama Makassar pada tanggal 12 Mei 2013.

Damopolii, Muljono. 2005. Pembaruan Pendidikan Islam di Makassar (Studi Kasus Pesantren Modern Pendidikan Al Qur'an IMMIM Tamalanrea Makassar. Disertasi (belum terbit). Jakarta: Program Pascasarjana UIN Syarif Hidayatullah Jakarta.

Dhofier, Zamakhsyari. 1994. Tradisi Pesantren: Studi Tentang Pandangan Kyai. Jakarta: LP3ES.

Halim, Wahyuddin. 2015. As'adiyah Traditions: The Construcion and Reproduction of Religious Authority in Contemprary South Sulawesi (Disertasi, belum terbit). Australia: Australian National University.

Mastuhu. 1994. Dinamika Sistem Pendidikan Pesantren; Suatu Kajian Tentang Unsur dan Nilai Sistem Pendidikan Pesantren. Jakarta: INIS.

al-Ma'luf, Louis. 1986. al-Munjid $f i$ al-Lugati wa al-A'lam. Cet. XXXVIII; Libanon: Dar alMasyriq.

Muchsin, Agus. 2014. Konstruksi Kaderisasi Ulama Pondok Pesantren As 'adiyah Sengkang dan Pondok Pesantren Darud Dakwah wal Irsyad Mangkoso: Tinjauan Terhadap Manhaj Fikih Pesanttren (disertasi, belum Terbit). Makassar: Program
Pascasarjana UIN Alauddin Makassar.

Munawwir, A.W. 1997. Kamus alMunawwir Arab-Indonesia Terlengkap. Cet. XIV; Surabaya: Pustaka Progressif.

Parwadi, Redatin. 2006. Kaderisasi Organisasi dalam Perubahan. Jurnal Wawasan, Volume 12 Nomor 1.

Ruslan, Muhammad dan Waspada Santing. 2007. Ulama Sulawesi Selatan: Biografi Pendidikan dan Dakwah. Makassar: Komisi Informasi dan Komunikasi MUI Sulsel.

Saprillah. 2014. Pengabdian tanpa Batas: Biografi Anregurutta Haji Abdul Malik Muhammad. Cet. I: ZADAHANIFA.

Shihab, Quraish. 2007. Ensiklopedia al-Qur'an: Kajian Kosakata. Jilid III. Cet. I; Jakarta: Lentera Hati.

al-Sijistani, Abu Dawud Sulaiman bin al-Asy'ats. T.th. Sunan Abi Dawud, Juz III. Beirut: Dar alKitab al-Arabi.

Sugiyono. 2010. Metode Penelitian Pendidikan (Pendekatan Kualitatif, Kuantitatif, dan $R$ \& $D)$. Bandung: Alfabeta.

Tamrin, M. t.th. Metodologi Dakwah. Jakarta: YPI Ibnu Sina.

Tim Penyusun Kamus Pusat Pembinaan dan Pengembangan Bahasa Departemen Pendidikan dan Kebudayaan. 1990. Kamus Besar Bahasa Indonesia. Cet. III. Jakarta: Balai Pustaka.

Ziemek, Manfred. 1986. Pesantren dalam Perubahan Sosial. Jakarta: P3M. 